\title{
CPTAC Medical History Form
}

National Cancer Institute

\section{Source}

National Cancer Institute. CPTAC Medical History Form. NCI Thesaurus. Code C156954.

Terminology used in support of the data collection efforts of the Clinical Proteomic

Tumor Analysis Consortium (CPTAC) with the focus on Medical History Form data. 